\title{
23. FRONTAL THRUST, OREGON ACCRETIONARY PRISM: GEOMETRY, PHYSICAL PROPERTIES, AND FLUID PRESSURE
}

\author{
J. Casey Moore, ${ }^{2}$ Kate Moran, ${ }^{3}$ Mary E. MacKay, ${ }^{4}$ and Harold Tobin ${ }^{2}$
}

\begin{abstract}
The frontal thrust of the Oregon accretionary prism scrapes off about $2 \mathrm{~km}$ of incoming sedimentary section and underlies a fault-bend fold of the first ridge landward of the abyssal plain. Scarps with associated chemosynthetic biological communities at the surface and pore-water anomalies at depth indicate that the frontal thrust is tectonically and hydrologically active. At Site 891 , near seismic line OR-5, the thrust splits into at least three splays from 375 to 500 mbsf. The upper splay is defined in the cores by strongly developed scaly fabric and is mostly positive polarity on seismic reflection lines. The middle splay shows low to moderate deformation in the cores. Drilling did not penetrate the lower splay. The middle and lower splays are mostly negative polarity on the seismic reflection data. At Ocean Drilling Program (ODP) Site 891 the upper splay is marked by increased velocity and density on borehole logs, which explains its positive polarity reflection. In core samples the middle splay is associated with a velocity and density decrease about $10 \mathrm{~m}$ thick that explains its negative polarity reflection.

Four techniques were used to estimate fluid pressure from the anomalously porous interval associated with the middle splay of the frontal thrust: (1) comparison of porosity and effective overburden to an undeformed reference section in Cascadia Basin; (2) comparison of the porosity-depth profile over this interval with the normally consolidated porosity-depth function determined from one-dimensional consolidation tests on recovered samples; (3) comparison of the undrained shear strength/ overburden pressure ratio $\left(\mathrm{S}_{\mathrm{u}} / \mathrm{P}_{\mathrm{o}}{ }^{\prime}\right)$ with the same ratio for normally consolidated clays; and (4) direct measurement of sediment stress history from consolidation tests. These four methods result in a range of fluid pressure ratios $(\lambda)$ from 0.88 to 0.99 that indicates nearly lithostatic fluid pressures associated with the middle splay of the frontal thrust.

Overall the frontal thrust at Site 891 evolves from a fluid-rich, high-fluid-pressure state, as exemplified by the middle and lower splays, to the dense, collapsed mature state of the upper splay. The frontal thrust is thus undergoing "in sequence" or seaward migration into the footwall, associated with dewatering and densification. Rapid burial of the highly porous sediment associated with the middle splay preserved near-surface effective stresses by high fluid pressures, which were perhaps temporarily sealed by the low transverse permeability of the enveloping fault strands.
\end{abstract}

\section{INTRODUCTION}

At convergent margins, frontal thrusts are the most fundamental tectonic boundary cropping out at the surface, and typically mark a major break in slope and probably represent the locality of the highest strain rate. In the Ocean Drilling Program (ODP) Leg 146 area, the frontal thrust is characterized by a large displacement and by negative polarity seismic reflections that are arguably associated with intervals of high fluid pressure (Moore et al., in press; Tobin et al., 1994). Similar negative polarity reflectors are common on frontal thrusts and décollements at many convergent margins, where they are interpreted as simple thrust inversions of physical properties (Shipley et al., 1990; Moore and Shipley, 1993) or zones of discrete dilation in the fault surface (Bangs and Westbrook, 1991; Cochrane et al., 1994b; Shipley et al., 1994). In these studies, the seismic reflection data are a principal proxy for the physical and fluid properties of the rocks in and around the fault surface. These proxies demand groundtruthing by the few boreholes through frontal thrusts. Site 891 does, at least, penetrate into the frontal thrust zone. Although the recovery

'Carson, B., Westbrook, G.K., Musgrave, R.J., and Suess, E. (Eds.), 1995. Proc ODP, Sci. Results, 146 (Pt. 1): College Station, TX (Ocean Drilling Program).

${ }^{2}$ Earth Sci., University of California at Santa Cruz, Santa Cruz, CA 95064, U.S.A

${ }^{3}$ Atlantic Geoscience Centre, Bedford Institute of Oceanography, Dartmouth, Nova Scotia B2Y 4A2, Canada.

${ }^{4}$ SOEST, University of Hawaii, Honolulu, HI 96822, U.S.A. was sporadic, the cores and associated logs provide a readily interpretable record of fluid and structural history.

\section{TECTONIC SETTING}

The Oregon-Washington subduction zone is characterized by copious clastic sediment influx and a young oceanic plate. A topographic trench is absent nearly everywhere as two large submarine fans dominate the depositional system. Our research is focused offshore central Oregon (Fig. 1). Here, the age of the oceanic crust is about 9 $\mathrm{Ma}$, converges at a rate of approximately $4 \mathrm{~cm} / \mathrm{yr}$ along $070^{\circ}$, and is covered by about $3.5 \mathrm{~km}$ of sediment (Kulm et al., 1984; Demets et al., 1990). This area of central Oregon contains distinct domains of landward- and seaward-verging structures (Kulm et al., 1973; Snavely and Miller, 1986; MacKay et al., 1992). Our study is from a province of seaward-vergent structures.

Depositional, diagenetic, and tectonic aspects of the sediments incoming to the margin all suggest overpressuring. Depositional rates of about $1 \mathrm{~km} / \mathrm{m}$.y. in the incoming submarine fan turbidite sequence probably generate high fluid pressures (Moore et al., in press). Additionally, a geothermal gradient of about $60 \% \mathrm{~km}$ (A. Fisher, pers. comm., 1994; Shipboard Scientific Party, 1994a) would allow clay mineral dehydration (Pytte and Reynolds, 1989) and hydrocarbon generation reactions (Tissot and Welte, 1984) to contribute to overpressuring within $2 \mathrm{~km}$ of the surface. Finally, the porosity decrease and incipient thrusting occurring seaward of the frontal thrust could 


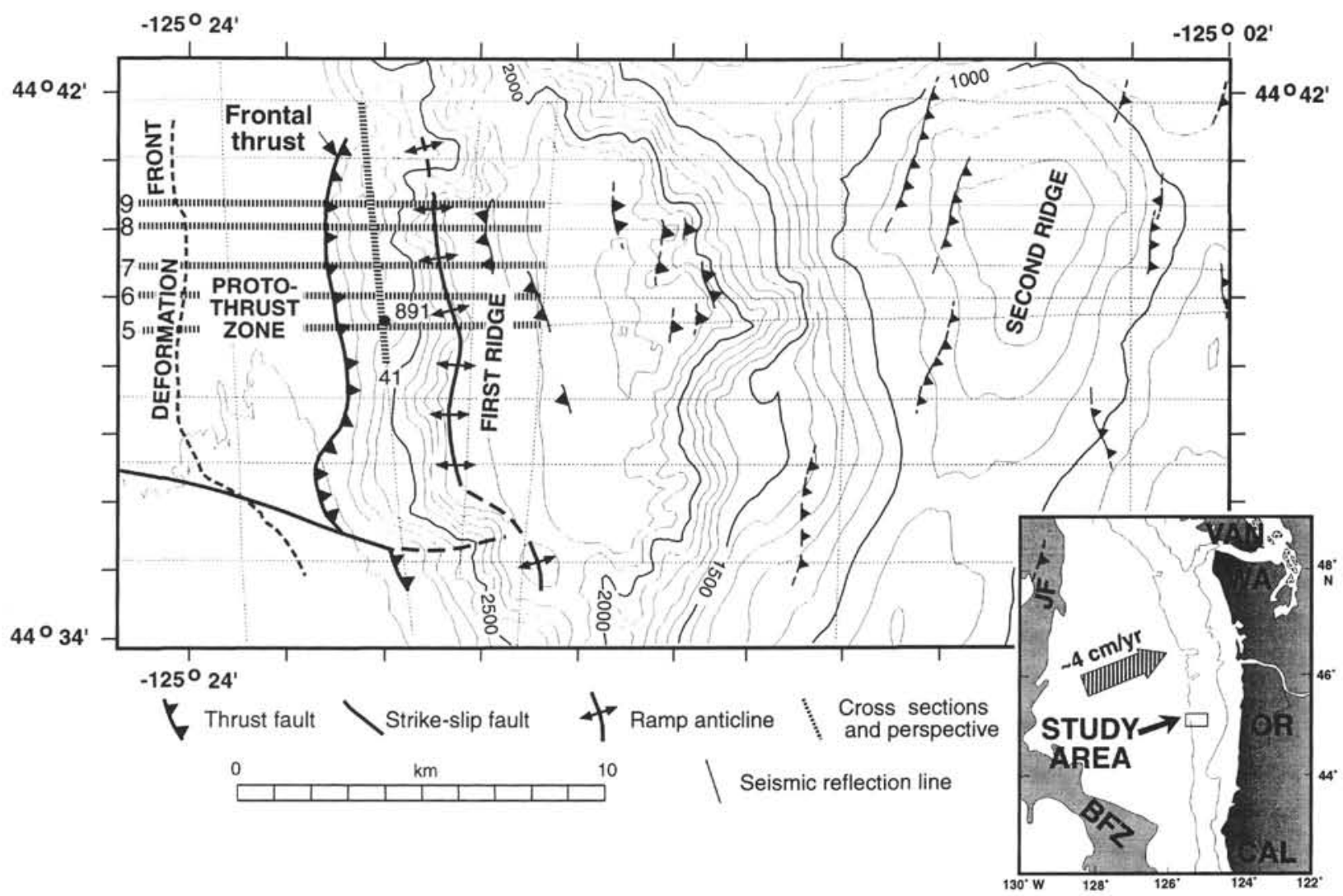

Figure 1. Bathymetric map and major structural features of seaward-vergent portion of Oregon margin. After MacKay et al. (1992).

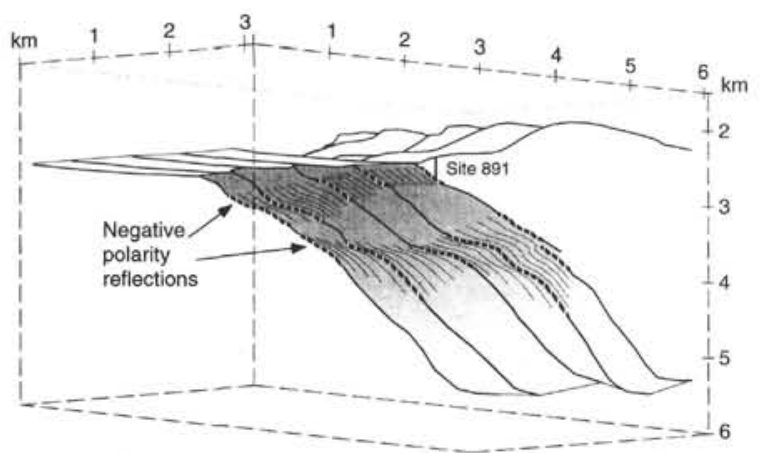

Figure 2. Perspective diagram that views frontal thrust from the southwest and shows how polarity reversals occur in two depth-delimited bands (after Moore et al., in press).

tectonically overpressure the incoming sedimentary section (Cochrane et al., 1994b).

\section{FRONTAL THRUST GEOMETRY AND GEOLOGY}

In the vicinity of ODP Site 891 , the frontal thrust of the Oregon accretionary prism dips landward, has a vertical throw of about 1.2 $\mathrm{km}$, and controls the geometry of a fault-bend fold that underlies the first ridge of the margin (MacKay et al., 1992; Cochrane et al., 1994a) (Figs. 1 and 2). A zone of incipient thrusting, the "proto-thrust zone," flanks the frontal thrust on its westward margin (MacKay et al., 1992; Cochrane et al., 1994a).
The correlation of faults defined on the seismic reflection data and the features from cores requires correct depth conversion of the seismic data. The seismic data were depth converted using velocities derived from the ODP drilling, associated logs, and vertical seismic profiles (Cochrane et al., 1994a). We determined the depth of the thrust splays by subtracting the depth of the water-bottom reflector from the reflectors of the fault splays on seismic line OR-41 that trends north-south within $20 \mathrm{~m}$ west of Site 891 and intersects line OR-5, $60 \mathrm{~m}$ south of the drill site. Additionally, we adjusted for the 7-m shallower water depth of Site 891 and the closest approach of seismic line OR-41. Seismic line OR-41 runs parallel to the structural strike. Because the water-bottom and thrust splays dip perpendicular to the section, their dips are not migrated in the 2-dimensional migration process. However, because the magnitude of the dips on both interfaces is similar, the time (and depth) differences between the migrated and unmigrated sections are similar. Moreover, the fault splays match well at the intersection of Lines 8 and 41 , indicating that the depth differences due to migration (or effective lack thereof) are not large. To allow for errors in migration in the depth conversion, as well as errors in the physical location of the site and seismic line, the depths of the thrust splays determined from the seismic data are displayed in figures as a band $30 \mathrm{~m}$ in thickness ( $\pm 3 \%-4 \%$ error $)$, centered on the best value (Figs. 4, 5, 6, and 7).

The frontal thrust splits into at least three splays near the surface along seismic line OR-5, which lies just south of Site 891 (Fig. 3). The upper splay cuts the drill hole at $375 \pm 15 \mathrm{~m}$ below seafloor (mbsf) and is associated with the most highly developed scaly fabric at Site 891 (Fig. 4; Teas et al., this volume) This upper splay is located at about $370 \mathrm{~m}$ sub-bottom on the seismic data. On the seismic data, the middle splay occurs at about $426 \pm 15$ mbsf in correlation with a cored section that is not structurally complex overall, but lies near interval of deformation bands at 437 mbsf. Located at $500 \pm 15 \mathrm{mbsf}$ 


\section{A}

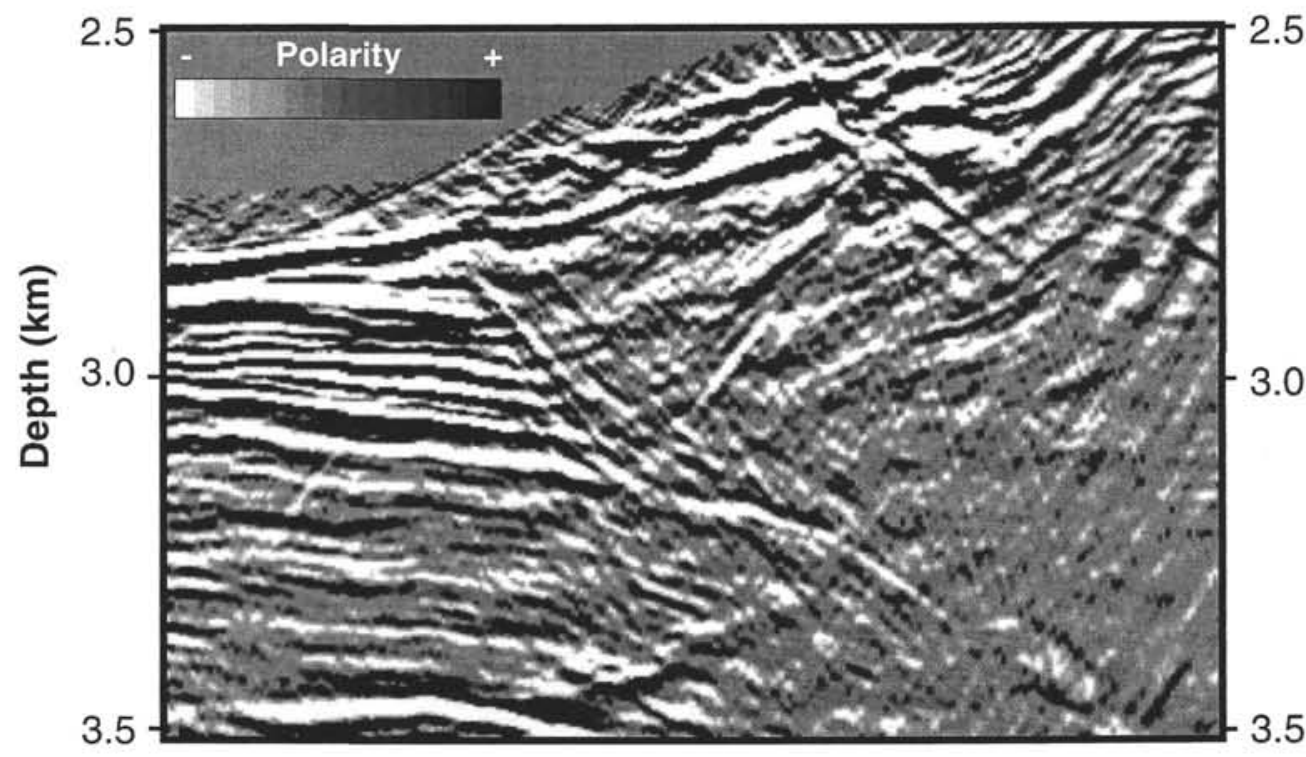

$\frac{\text { Eิ }}{\text { 동 }}$

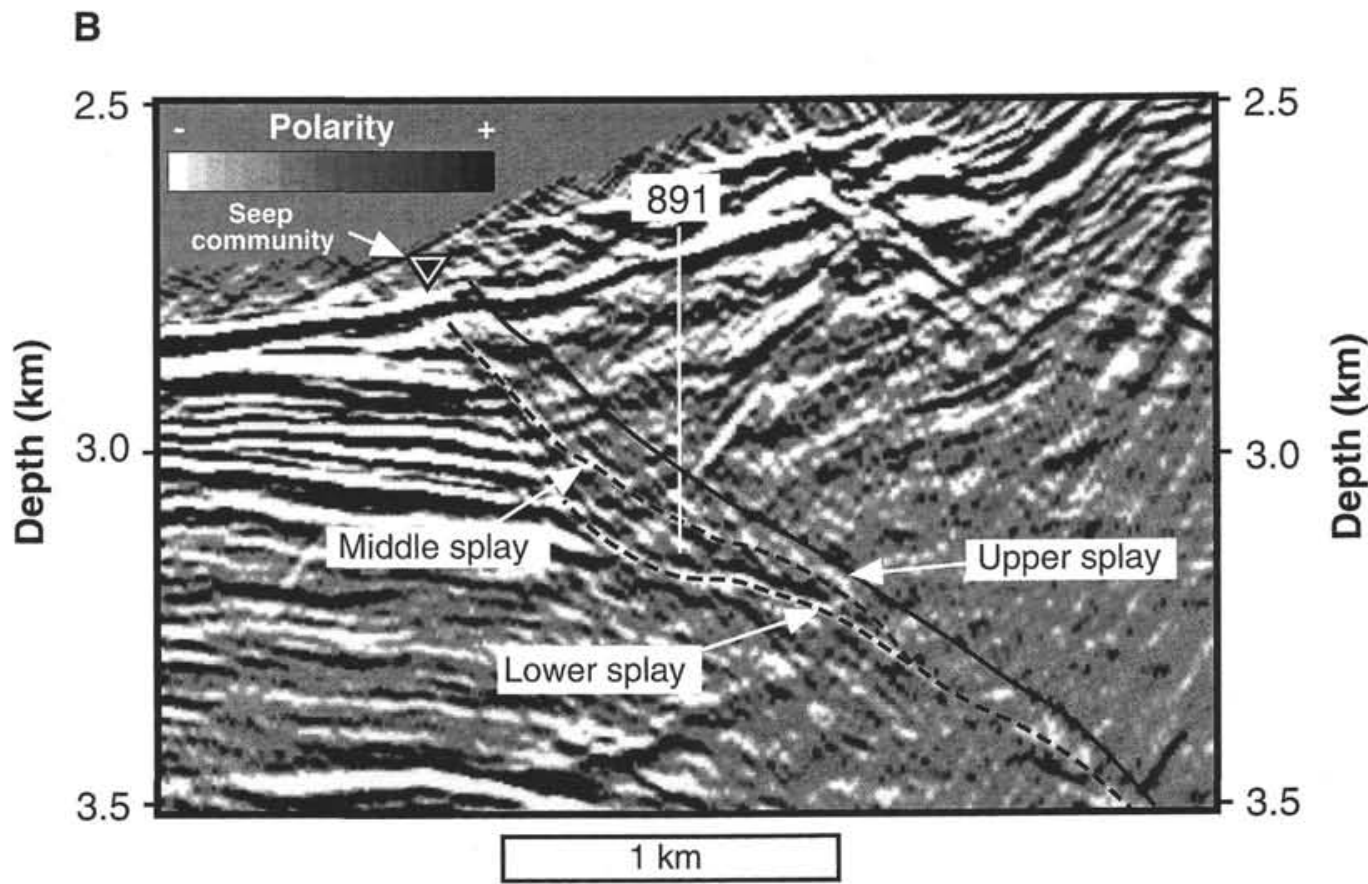

Figure 3. Detail of seismic line OR-5 (A. uninterpreted; B. interpreted). The true amplitude display has a vertical exaggeration is about $2 \times$. Note correlation of the chemosynthetic biological community at the surface with outcrop of fault. At the seafloor, the composite positive reflection is a small negative, large positive, and a large negative or white-black-white (seafloor at about $2.85 \mathrm{~km}$, left side of $(\mathrm{A})$. The most dominant visual feature of this complex waveform is the positive, shown as black on the variable density display. Conversely composite negative polarity reflections consist of a small positive, a large negative reflection and a large negative.

on the seismic data at Site 891 , the lower splay was not penetrated by drilling. The thrust splays defined here are the most clearly shown in the seismic reflection data; additional splays could be defined by more detailed seismic interpretation.

Both surface biological activity and pore-water chemistry from the drill cores indicate active flow along the frontal thrust near Site 891 (Figs. 3 and 4; Moore et al., 1990; Shipboard Scientific Party, 1994b). The frontal thrust crops out at the location of a chemosynthetic biological community indicating active seepage along this fault. At 411 mbsf the cores are enriched in ethane, which suggests the migration of deeply sourced fluids near the middle splay of the frontal thrust. There is no significant anomaly in organic geochemistry along the splay at $375 \mathrm{mbsf}$.

\section{FRONTAL THRUST: REFLECTION POLARITY}

Seismic reflections from the frontal thrust and proto-thrusts include notable zones of negative polarity that are interpreted as intervals of anomalously high fluid pressure (Moore et al., in press). The 


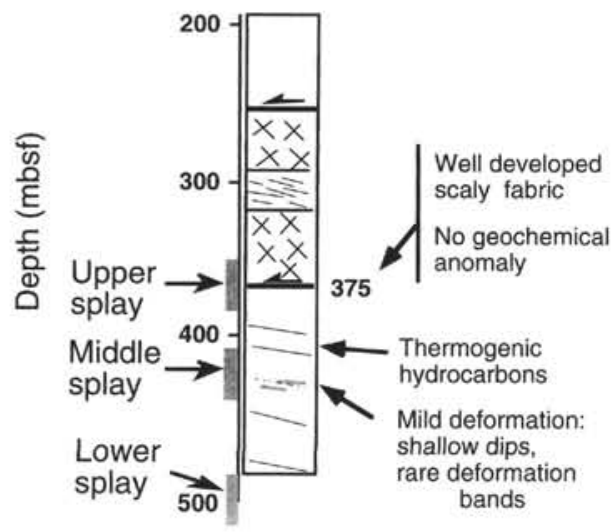

Figure 4. Summary of structural features and pore water geochemical anomalies at Site 891 (Shipboard Scientific Party, 1994b) as related to splays of the frontal thrust interpreted from seismic reflection data. Note the excellent correlation between the well-developed fault at $375 \mathrm{mbsf}$ in the cores and the upper splay of frontal thrust.
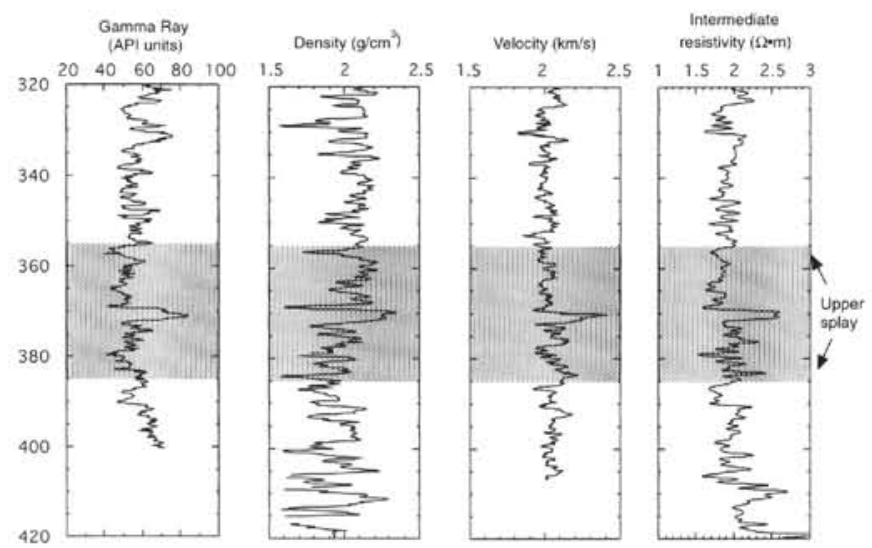

Figure 5. Borehole logs from Site 891. Note the high values of gamma ray, density, velocity and resistivity at $369-374 \mathrm{~m}$. The high in the density log is less pronounced because its quality is affected by variations in hole diameter. All responses are consistent with a collapse densification along this fault surface. The stippled area defines range location for upper splay estimated from seismic reflection data.

intervals of negative polarity reflections lie in bands along the frontal thrust; drilling at Site 891 penetrated the frontal thrust through the shallower of the two bands (Fig. 2).

Determination of reflection polarity requires appreciation of the full geometry of the waveform. At the seafloor, the positive reflection is a small negative, large positive, and a large negative (left side of Fig. 3A). The most dominant visual feature of this complex waveform is the positive, shown as black on the variable density display (Fig. 3). Conversely negative polarity reflections consist of a small positive, a large negative reflection and a large positive. The most visually striking feature of this complex reflection is the large negative, shown as the white portions of the variable density display (Fig. 3). The waveforms are locally modified by interference from other adjacent reflectors; waveform shape and lateral continuity has been affected by tuning effects and cross-cutting diffractions from sources both in and out of the plane of the section. Our interpretations are drawn on the dominant positive of the compound positive waveform and the dominant negative of the composite negative waveform.
The frontal thrust at Site 891 lies in an interval of dominantly negative polarity (Fig. 2). However, the polarity of the fault-plane reflections is complicated in detail. Of the three splays, the upper is dominantly positive polarity, and the middle and lower are mostly negative polarity (Fig. 3). At the location of Site 891 the reflection polarity of the upper splay is ambiguous, due to interference from a diffraction, but the positive polarity is well shown along its deeper extension. The negative polarity reflection of the middle splay is most prominent at depths less than $3050 \mathrm{~m}$ below sea level (mbsl), whereas the negative polarity reflection on the lower splay is clearest at depths greater than $3100 \mathrm{mbsl}$.

\section{CHANGES IN PHYSICAL PROPERTIES ACROSS THE UPPER MIDDLE SPLAYS OF THE FRONTAL THRUST}

Changes in physical properties across the frontal thrust can be evaluated from velocities derived from the processing of the multichannel seismic (MCS) data, from borehole logs, and from measurements on core samples.

\section{Upper Splay}

The upper splay of the frontal thrust ( $375 \pm 15 \mathrm{mbsf}$ ) coincides with high borehole log values in gamma ray, density, velocity, and resistivity from 369-374 m (Figs. 5 and 6). Such log responses indicate collapse and densification of the sedimentary fabric. The physical property measurements on cores do not show a response comparable to that seen in the logs, perhaps because the discrete samples are scattered and dependent on core recovery. Moreover, discrete samples tend not to be taken from the more sheared material. A synthetic seismogram created from the log data indicates a positive polarity reflection (Shipboard Scientific Party, 1994b).

\section{Middle Splay}

The middle splay of the frontal thrust $(426 \pm 15 \mathrm{mbsf})$ is below the interval where logs were collected; analysis of this splay's physical properties relies on the physical properties determined from core samples. Because of elastic rebound and micro-cracking during sample recovery, velocities derived from core samples are lower than those derived from the logs (Fig. 6). The velocities measured in samples increase along a similar trend to the log-derived velocities above the middle splay, but show a pronounced drop below $438 \mathrm{mbsf}$ at Site 891. Although Hole 891B extends to $473 \mathrm{mbsf}$, samples below 450 mbsf were unsuitable for velocity measurements.

Porosity and bulk-density measurements on core samples show large increases and decreases, respectively, at about $438 \mathrm{mbsf}$ and return to the background values below $448 \mathrm{mbsf}$. This anomalously porous interval averages $51 \%$, locally reaching a high of $61 \%$. The high-porosity and low-density interval correlates with the interval of decreased velocity.

The measured porosity-depth profile at Site 891 is compared with the normally consolidated porosity-depth profile (Fig. 7) determined from one-dimensional consolidation tests and following the procedure described by MacKillop et al. (1995). In most of the section above $\sim 420 \mathrm{mbsf}$, measured porosity values are less than the predicted normally consolidated porosity, which suggests an overconsolidated sediment section. Exceptions occur at about $300 \mathrm{mbsf}$, about $375 \mathrm{mbsf}$, and below $448 \mathrm{mbsf}$ where the core approaches normal consolidation. The interval from 438 to 448 mbsf is clearly underconsolidated.

In summary, from 438 to 448 mbsf measured porosity values are higher than predicted, which indicates underconsolidation and high 


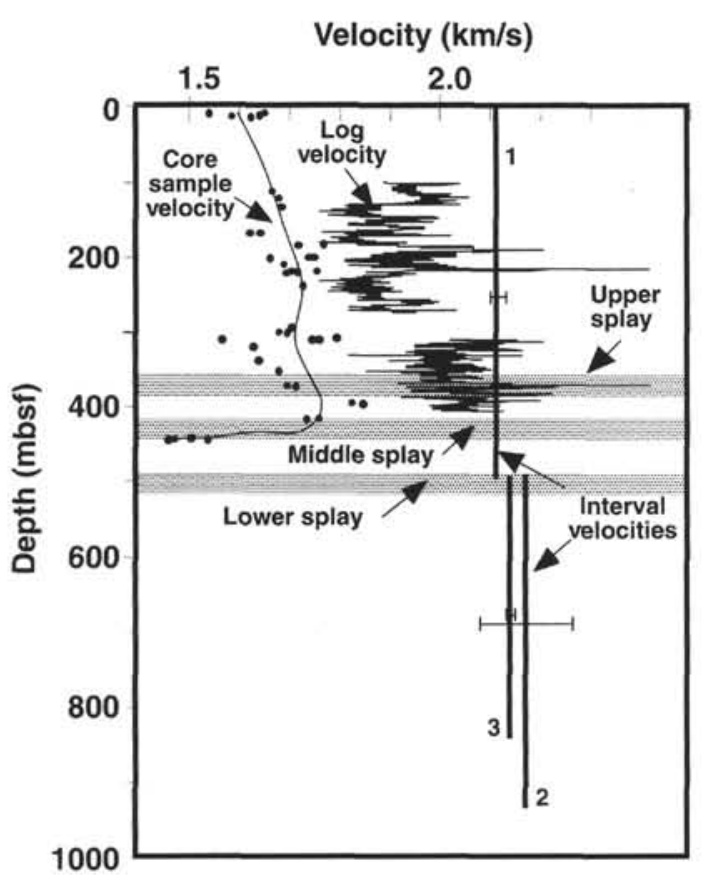

Figure 6. Summary of velocity data from Site 891 and vicinity. Stippled bars indicate depths of fault splays determined from seismic data. Note the velocity spike in the log data associated with the upper splay of the frontal thrust The velocity measurements from the cores extend into but not through the middle thrust splay. The core velocities suggest an impedance drop within the middle splay, on a scale finer than the resolution of the interval velocities. Note that in spite of a fault throw of $1.2 \mathrm{~km}$, the hanging wall (entire section above the lower splay) has a slightly lower velocity than the footwall. Apparently the large-scale overthrusting process causes a dilation and velocity reduction in the hanging wall (Lewis, 1991; Cochrane et al., 1994b). Interval velocities are determined from semblance velocities from seismic processing. Interval velocity data shown on bars 1 and 2 are from north-south strike line (line 41, Fig. 1) through Site 891. Data in bar 3 are from section equivalent to bar 2 but in a sedimentary basin $5 \mathrm{~km}$ to west. Error bars show the standard deviation of 5 velocity analyses. Bar 3 verifies that the measurements in bar 2 are representative of the section being overthrust. The core velocities are less than the interval and $\log$ velocities, in part because of the effects of unloading (e.g., Karig, 1993).

excess fluid pressure. Together, the velocity drop and the low-porosity interval determined from individual samples indicate a thin underconsolidated sediment zone, about $10 \mathrm{~m}$ thick. This anomalously porous interval overlaps the lower limit (441 mbsf) of the middle splay of the frontal thrust. The waveform of the negative polarity reflection of this splay could be produced by the low velocity-low density (low impedance) interval. Waveform models that use a comparable thickness and impedance decrease convincingly reproduce a negative polarity waveform (see Moore et al., in press; Tobin et al., this volume).

\section{Lower Splay}

Because the lower splay of the frontal thrust was not penetrated by drilling, its physical properties are evaluated only from the seismic reflection data. Cochrane et al., (1994a, 1994b) have converted the stacking velocities necessary to process the MCS data to interval velocities across the marginal ridge in the Site 891 area. Near the drilling location, the hanging wall of the frontal thrust (entire section

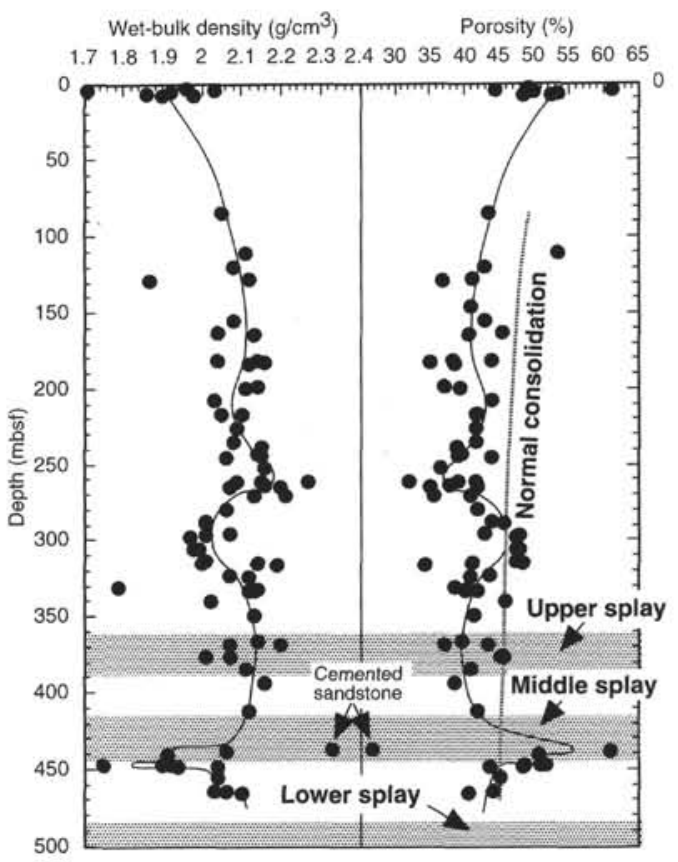

Figure 7. Bulk density and porosity from cores relative to the seismically determined location of frontal thrust splays. The lower location range of the middle splay overlaps with a pronounced drop in density and increase in porosity; this density-porosity anomaly correlates with a drop in velocity (Fig. 6). The normal consolidation curve compares sediment consolidated under hydrostatic conditions to the observed porosity. Note that the highly porous section associated with the middle splay of the frontal thrust is underconsolidated.

above the lower splay) shows an interval velocity (Fig. 6, bar 1) slightly lower than that of the unit immediately beneath (Fig. 6, bar 2) or its equivalent westward in the proto-thrust zone (Fig. 6, bar 3).

The lower velocity in the hanging wall with respect to the footwall is unexpected, given the $1.2 \mathrm{~km}$ of vertical throw on the fault; this uplift of more deeply buried material should result in a velocity and density inversion. The lower velocity in the hanging wall is shown both in the interval velocities determined by Cochrane et al. (1994b) and has been verified by seismic refraction (Lewis, 1991). Lewis (1991) and Cochrane et al. (1994b) believe that the marginal ridge undergoes a subtle dilation during uplift that reduces the velocity. Initial thrusting into the landward vergent ridge about $20 \mathrm{~km}$ north also causes a decrease in velocity in the uplifted sediments (M. MacKay et al., pers. comm., 1994) that is attributed to extension or decementation. The hanging wall below the upper splay of the frontal thrust appears to have incorporated sediments from the footwall, which would be of lower velocity. Because the interval velocity is an average of the entire section, these lower-velocity additions would decrease the overall velocity of the hanging wall.

The transition from lower to higher interval velocities across the hanging wall can be interpreted in two ways: (1) Because the hanging wall is of lower velocity than the footwall in the Site 891 area, simple thrust inversion may not create the negative polarity reflection. The negative polarity may be created by a localized zone of low velocity and density similar to that which occurs along the middle splay of the frontal thrust. (2) Because the interval velocities are average velocities, each interval velocity may have a gradient of increasing velocity with depth. Accordingly, the velocity at the base of the upper interval could be higher than that at the top of the lower interval, creating a negative polarity reflection. 


\section{ESTIMATES OF FLUID PRESSURE ALONG THE MIDDLE SPLAY OF THE FRONTAL THRUST}

The anomalously high porosity and the low density and uncemented nature of the sediments of the middle splay of the frontal thrust suggest high fluid pressure. Although there is no exact method to determine fluid pressure from such porosity and density anomalies, several approaches provide minimum estimates. All of our fluid pressure estimates are expressed as a ratio of fluid pressure to total stress. The total vertical stress (overburden or lithostatic stress) near the base of the middle splay of the frontal thrust at Site 891 (448 mbsf) is $9.0 \mathrm{MPa}$ (4.5 MPa hydrostatic pressure and 4.5 MPa effective overburden). Any values of overpressure that we have estimated are added to the hydrostatic stress; the ratio of this summed fluid pressure over total vertical stress represents the fluid pressure ratio or ( $\lambda$ ).

\section{Estimates from Porosity Comparisons to Reference Section}

The effective stress necessary to produce a given porosity can be determined by comparing the porosity of a given sediment to a reference section that is assumed to be hydrostatically pressured (e.g., Magara, 1978; Westbrook, 1991). At Site 891 the interval of underconsolidated sediments has a mean porosity of $51 \%$, based on measurements in the 438 to $448 \mathrm{mbsf}$ depth range. This porosity is equivalent to that developed at $120 \mathrm{mbsf}$ depth at Site 888 , a reference site drilled in the submarine fan off Vancouver Island (Fig. 8; Shipboard Scientific Party, 1994a). If the sediment at Site 888 is not overpressured at this depth, it specifies the effective overburden stress (about $1 \mathrm{MPa}$ ) for a porosity state of $51 \%$. The remainder of the $9 \mathrm{MPa}$ total stress at $450 \mathrm{mbsf}$ at Site 891 ( $8 \mathrm{MPa}$ ) must be supported by the fluid pressure, thus yielding a fluid-pressure ratio of 0.88 . Any overpressuring in the "reference" section results in an overestimate of the effective overburden and, therefore, an underestimate of the fluid pressure. The turbidite fan sequence at 888 was rapidly deposited and probably is overpressured.

\section{Estimates from a General Consolidation Curve}

Consolidation tests define the relationship between effective stress and porosity or void ratio for the sediment type tested. Accordingly, we can construct a curve of porosity or void ratio for sediment that is buried under hydrostatic conditions (Fig. 7). If the porosity is higher than predicted, the section is overpressured; if the porosity is lower than predicted, the section is overconsolidated, has been subjected to higher than current effective stresses, and may have been uplifted.

Here we use the difference between the measured porosity and the predicted normally-consolidated porosity, in terms of void ratio (e), to estimate excess fluid pressure (Fig. 7). From one-dimensional consolidation tests, the relationship between the normally consolidated void ratio and overburden stress is defined by two samples from Site 891. Clayey silts, silts, and sands dominate the single lithologic unit at Site 891. The consolidation tests and most of the physical property measurements were made on the dominant fine-grained lithology. We assume the consolidation tests represent the overall plastic and elastic deformation characteristics of this sediment. The relationship, derived from the virgin compression curves is as follows (Moran and Gray, this volume):

$$
D e=0.17 \log P_{o}^{\prime}
$$

where $D e$ is the change in void ratio from initial depositional void ratio to its consolidated void ratio and $P_{o}^{\prime}$ is the effective normally

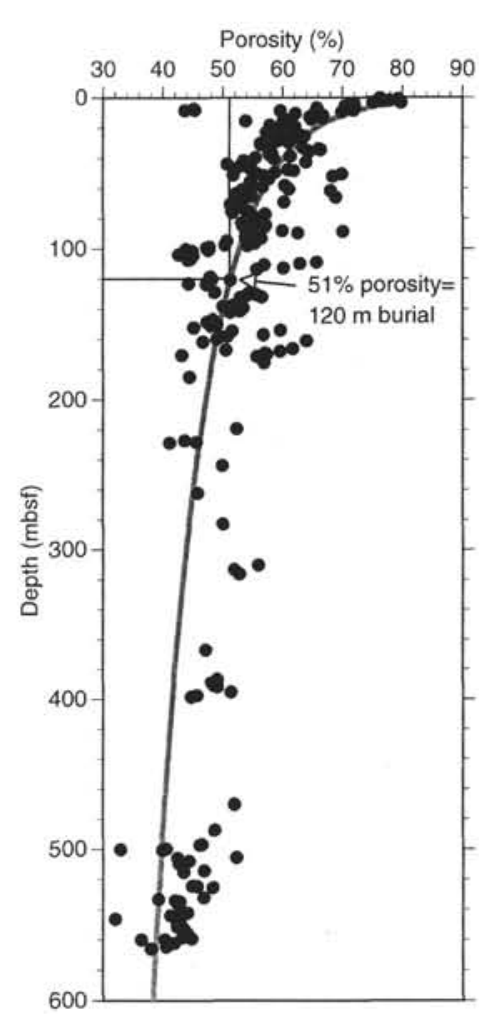

Figure 8 . The porosity-depth distribution at "reference" Site 888 shows how a porosity of $51 \%$ (associated with middle splay of frontal thrust) would intersect the curve at burial depth of $120 \mathrm{mbsf}$. This depth then is equivalent to the effective overburden in the high-porosity zone associated with the middle splay of the frontal thrust, if the section at Site 888 is not overpressured. If overpressured, the effective overburden would be less. The effective overburden calculated by this means indicates an fluid pressure ratio of about 0.88 at Site 891 near the middle splay of the frontal thrust.

consolidated overburden stress. The initial void ratio is determined from the average void ratio of sediment sampled in the piston core recovered from the sediment/water interface at this site. Using the average of measured void ratios over the sampled interval of the middle splay, the average $D e$ of the middle splay is 0.51 . From equation (1), the normally consolidated $D e$ is 0.62 (using an effective stress of 4.5 MPa or $4500 \mathrm{Kpa}$ ) This difference in void ratio corresponds with an effective stress difference of $3.6 \mathrm{MPa}$, which is equivalent to the excess fluid pressure within the depth interval of the middle splay. Using this method, the estimated fluid pressure is 4.5 $\mathrm{MPa}$ (hydrostatic) plus $3.6 \mathrm{MPa}$ excess with a fluid pressure ratio $(\lambda)$ of 0.9 .

\section{Estimates from Undrained Shear Strength}

Undrained shear strength measurements $\left(S_{u}\right)$ on recovered core samples at Site 891 (Shipboard Scientific Party, 1994b) are compared with the effective overburden stress $\left(P_{o}^{\prime}\right)$, calculated from measured bulk density, in terms of the $S_{i} / P_{o}^{\prime}$ ratio. Normally consolidated finegrained sediment have $S_{1} / P_{o}^{\prime}$ values that vary from 0.20 to 0.25 (Mesri, 1975). By comparing normally consolidated shear strength, based on the $S_{l} / P_{o}^{\prime}$ ratio with the measured shear strength from Site 891 , excess fluid pressure can be estimated over the interval of the middle splay of the frontal thrust. The average $S_{u} / P_{o}{ }^{\prime}$ over the interval of the middle splay is 0.03 , indicating an underconsolidated section. Comparing this to the minimum normally consolidated ratio $(0.20)$ results in a lower limit estimate of excess fluid pressure of $3.8 \mathrm{MPa}$. Within 
the middle splay interval, this excess fluid pressure is equivalent to a fluid pressure ratio of $0.92(8.3 / 9.0 \mathrm{MPa})$.

\section{Estimates from Consolidation Tests of Samples from High-porosity Section}

One-dimensional consolidation tests on samples recovered from Site 891 show a range of consolidation behavior (under-, normally, and overconsolidated; Moran and Gray, this volume). One test was conducted on sediment recovered from the middle splay (447 mbsf). The results show that this sediment is heavily underconsolidated (Fig. 9). The preconsolidation stress (maximum past effective stress) is very low $(0.125 \mathrm{MPa})$. The fluid pressure supporting the high natural porosity in this sample would have to have been $8.875 \mathrm{MPa}(9$ $0.125 \mathrm{MPa}$ ). This high fluid pressure represents a fluid pressure ratio of 0.99 . This value is based on test results from the base of the middle splay, where porosity is highest, and most likely represents the upper range of $\lambda$ over this interval.

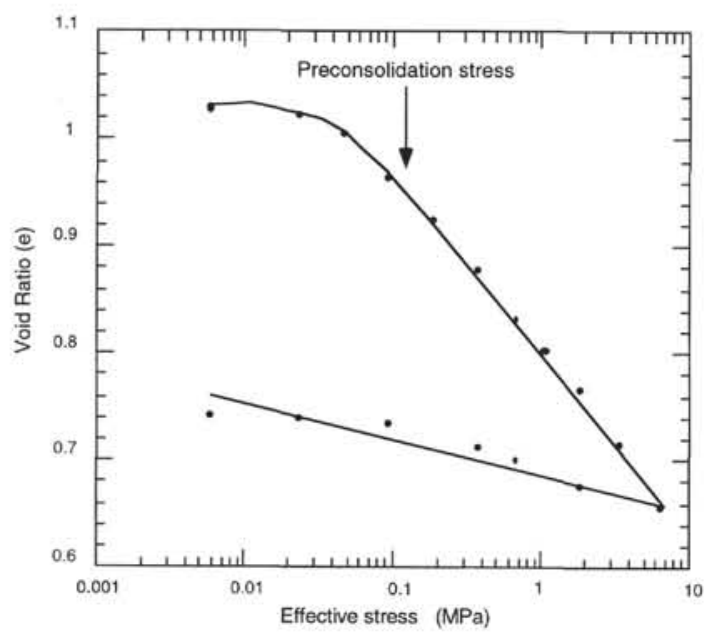

Figure 9. One-dimensional consolidation test from a sample at $447 \mathrm{mbsf}$ in the highly porous zone associated with middle splay of frontal thrust. The preconsolidation stress of $0.125 \mathrm{MPa}$ for this sample indicates heavy underconsolidation. The effective overburden is $1 \%-2 \%$ of the total stress at this locality, which indicates a fluid pressure ratio of 0.98 to 0.99 .

\section{Qualifications of Fluid Pressure Estimates}

The underconsolidated sediment in the middle splay of the frontal thrust zone has been consolidated by both overburden and lateral effective stress that exceeds the overburden. Thus, the mean stresses are higher than in a basinal setting or in a consolidation test, where the vertical effective stress is the maximum principal stress. By using the effective overburden of the reference site or consolidation tests and applying it to the frontal thrust, we overestimate the vertical effective overburden at Site 891 and underestimate the fluid pressure. However, as the fluid pressure increases, the effective stress values decrease, so any corrections to the effective stress values have less effect on the fluid pressure ratio.

\section{STRUCTURAL AND HYDROLOGIC MODEL OF FRONTAL THRUST DEVELOPMENT}

\section{Thrust Densification}

Information from Site 891 and adjacent seismic images suggests a model of fault evolution intimately tied to dewatering of the incoming sedimentary sequence. The increasing seaward coherency of the seismic stratigraphy of the basin fill and the less intense core-scale fabrics of the middle splay with respect to upper splay of the frontal thrust, suggest the upper splay has experienced more movement, and that it possibly developed earlier. This scenario would be consistent with "in sequence" thrust propagation in a basinward direction.

The upper splay of the frontal thrust has a strongly developed structural fabric and a mostly positive polarity on the seismic reflection data (Fig. 10). The log response indicates densification, probably associated with shear consolidation. The apparently less developed middle splay includes structural fabrics of low to moderate intensity, is associated with an interval of highly porous sediment, and shows a dominantly negative polarity reflection. The high porosity and low density of the sediment associated with the middle splay requires near-lithostatic overpressures. The high density of the upper splay indicates dewatering and probably lower fluid pressure. It is arguable whether the prominent negative polarity of the lower splay originates from thrust inversion or an interval of highly porous sediment within the fault zone.

\section{Origin of High-porosity Sediment}

The high-porosity sediment ( $438-448 \mathrm{mbsf})$ associated with the middle splay of the frontal thrust is remarkably undeformed. Consolidation characteristics indicate low past maximum effective stress and preservation of a shallow burial state, presumably by high fluid pressure. The low intensity of deformation and lack of a geochemical anomaly in pore water argues against the existence of an active shear zone permeated with high-pressure fluids that have migrated up the fault zone. Yet exotic fluids and moderately deformed sediments occur just above $(411 \mathrm{mbsf})$ the high-porosity zone. We interpret the high-porosity sediment as a remnant of the original sedimentary sequence, which has locally preserved porosity by enveloping it in shear zones of low transverse permeability (Brown et al., 1994;

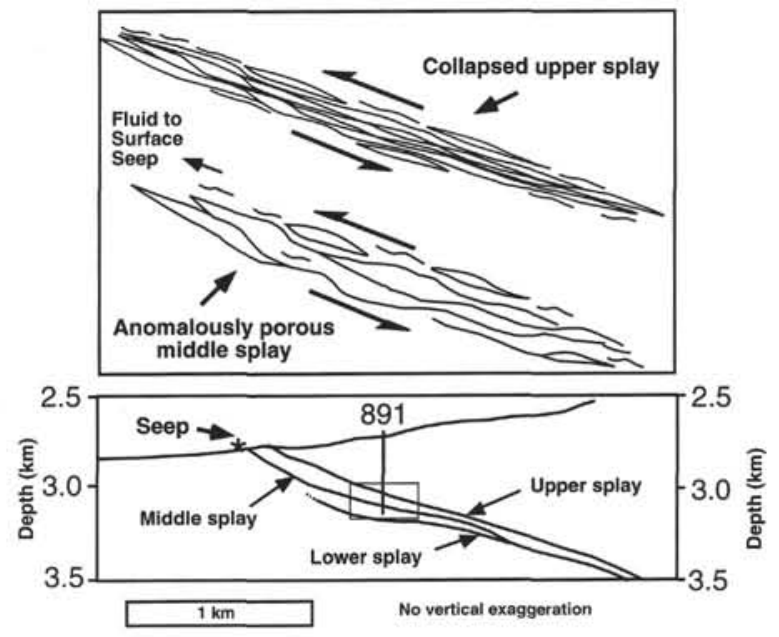

Figure 10. True scale cross section showing geometry of fault splays. Schematic above cross section conceptualizes fabric evolution from the middle to the upper splay. The anomalously porous middle splay exhibits minor fabric development, a local decrease in velocity and density, and a negative polarity reflection. The anomalously high porosity, low density, and low velocity indicates continuously high fluid pressure that has arrested consolidation. Retarded consolidation may be due to reduction of permeability by shear zones surrounding porous sediment lozenges. A continuous flux of fluid from depth at high pressures may also retard consolidation. The upper splay shows well-developed scaly fabric, positive density, velocity anomaly, and consequent positive reflection polarity. We believe that the upper splay has undergone collapse and strain hardening in evolution from a physical state similar to the current middle splay. 
Brown, this volume). In an active zone of thrusting, this high-porosity sediment is probably a transient state in the process of fluid loss and ripe for deformation, because of its high fluid pressure and propensity to failure.

\section{CONCLUSIONS}

The frontal thrust near Site 891 is tectonically and hydrologically active, as indicated by a prominent surface scarp, associated surface chemosynthetic biological communities, and a pore-water chemistry anomaly at depth. At least three fault splays define the frontal thrust on seismic reflection data. The upper splay shows an intensely developed structural fabric, high density and velocity on borehole logs, and a largely positive reflection polarity. It is probably an older, more highly sheared state of structural evolution. The middle splay can only be linked to a local zone of moderate deformation but is associated with a highly porous and highly overpressured sedimentary interval. This low velocity-density sedimentary interval probably creates the negative polarity reflection that characterizes the middle splay of the frontal thrust. This zone is in a transient state of near-failure conditions, which will produce active-dewatering through the process of shear consolidation. The lower splay of the frontal thrust probably represents a fluid-rich zone similar to but even less evolved than the middle splay.

\section{ACKNOWLEDGMENTS}

Financial support provided by USSAC grants for both shipboard participation and post-cruise science; NSF grants OCE-8813907 and OCE-9116368 supported collection, processing, and interpretation of the seismic data upon which this paper is based. Guy Cochrane was responsible for a substantial amount of the seismic processing. Landmark Graphics Corporation kindly provided the seismic interpretation software. Ed Boring and Gretchen Zwart supported the seismic interpretation software. Rich Jarrard led efforts in collecting the logging data presented here. Warner Bruckmann, Tom Shipley, and Graham Westbrook, provided insightful reviews.

\section{REFERENCES}

Bangs, N.L.B, and Westbrook, G.K., 1991. Seismic modeling of the décollement zone at the base of the Barbados Ridge accretionary complex. $J$. Geophys. Res., 96:3853-3866.

Brown, K.M., Bekins, B., Clennell, B., Dewhurst, D., and Westbrook, G., 1994. Heterogeneous hydrofracture development and accretionary fault dynamics. Geology, 22:259-262.

Cochrane, G.R., MacKay, M.E., Moore, G.F., and Moore, J.C., 1994a. Consolidation and deformation of sediments at the toe of the central Oregon accretionary prism from multichannel seismic data. In Westbrook, G.K., Carson, B., Musgrave, R.J., et al., Proc. ODP, Init. Repts., 146 (Pt. 1): College Station, TX (Ocean Drilling Program), 421-426.

Cochrane, G.R., Moore, J.C., MacKay, M.E., and Moore, G.F., 1994b. Velocity and inferred porosity model of the Oregon accretionary prism from multichannel seismic reflection data: implications on sediment dewatering and overpressure. J. Geophys. Res., 99:7033-7043.

Demets, C., Gordon, R.G., Argus, D.F., and Stein, S., 1990. Current plate motions. Geophys. J. Int., 101:425-478.

Karig, D.E., 1993. Reconsolidation tests and sonic velocity measurements of clay-rich sediments from the Nankai Trough. In Hill, I.A., Taira, A., Firth, J.V., et al., Proc. ODP, Sci. Results, 131: College Station, TX (Ocean Drilling Program), 247-260.

Kulm, L.D., Peterson, C.P., Connard, G.G., Johnson, S.Y., Niem, W.A., McClain, K.J., Loubere, P.W., Lewis, B.T.R., Couch, R.W., Scheideg- ger, K.F., Crosson, R.S., Stewart, R.J., and Niem, A.R., 1984. Western North American continental margin and adjacent ocean floor off Oregon and Washington. Ocean Margin Drilling Program: Regional Atlas Series, 1. Woods Hole, MA (Mar. Sci. Int.).

Kulm, L.D., Prince, R.A., and Snavely, P.D., Jr., 1973. Site survey of the Northern Oregon Continental Margin and Astoria Fan. In Kulm, L.D., von Huene R., et al., Init. Repts. DSDP, 18: Washington (U.S. Govt. Printing Office), 979-987.

Lewis, B.T.R., 1991. Changes in P and S velocities caused by subduction related sediment accretion off Washington/Oregon. In Hovem, J.M., Richardson, M.D., and Stoll, R.D. (Eds.), Shear Waves in Marine Sediments: Dordrecht (Kluwer), 379-386.

MacKay, M.E., Moore, G.F., Cochrane, G.R., Moore, J.C., and Kulm, L.D., 1992. Landward vergence and oblique structural trends in the Oregon margin accretionary prism: implications and effect on fluid flow. Earth Planet. Sci. Lett., 109:477-491.

MacKillop, A.K., Moran, K., Jarrett, K., Farrell, J., and Murray, D., 1995. Consolidation properties of equatorial Pacific sediment and their relationship to stress history and offsets in the Leg 138 composite depth sections. In Pisias, N.G., Mayer, L.A., Janecek, T.R., Palmer-Julson, A., and van Andel, T.H. (Eds.), Proc. ODP, Sci. Results, 138: College Station, TX (Ocean Drilling Program), 357-369.

Magara, K., 1978. Compaction and Fluid Migration: Practical Petroleum Geology, Dev. Pet. Sci., 9. Amsterdam (Elsevier).

Mesri, G., 1975. Discussion of new design procedures for stability of soft clays. J. Geotech. Div., Am. Soc. Civ. Eng., 101:409-412.

Moore, G.F., and Shipley, T.H., 1993. Character of the décollement in the Leg 131 area, Nankai Trough. In Hill, I.A., Taira, A., Firth, J.V., et al., Proc. ODP, Sci. Results, 131: College Station, TX (Ocean Drilling Program), 73-82.

Moore, J.C., Moore, G.F., Cochrane, G.R., and Tobin, H.J., in press. Negative-polarity seismic reflections along faults of the Oregon accretionary prism: indicators of overpressuring. J. Geophys. Res.

Moore, J.C., Orange, D., and Kulm, L.D., 1990. Interrelationship of fluid venting and structural evolution: Alvin observations from the frontal accretionary prism. J. Geophys. Res., 95:8795-8808.

Pytte, A.M., and Reynolds, R.C., 1989. The thermal transformation of smectite to illite. In Naeser, N.D., and McCulloh, T.H. (Eds.), Thermal History of Sedimentary Basins: Methods and Case Histories: New York (Springer), 133-140.

Shipboard Scientific Party, 1994a. Site 888. In Westbrook, G.K., Carson, B., Musgrave, R.J., et al., Proc. ODP, Init. Repts., 146 (Pt. 1): College Station, TX (Ocean Drilling Program), 55-125.

, 1994b. Site 891. In Westbrook, G.K., Carson, B., Musgrave, R.J., et al., Proc. ODP, Init. Repts., 146 (Pt. 1): College Station, TX (Ocean Drilling Program), 241-300.

Shipley, T.H., Moore, G.F., Bangs, N.L., Moore, J.C., and Stoffa, P.L., 1994. Seismically inferred dilatancy distribution, northern Barbados Ridge décollement: implications for fluid migration and fault strength. Geology, 22:411-414.

Shipley, T.H., Stoffa, P.L., and Dean, D.F., 1990. Underthrust sediments, fluid migration paths, and mud volcanoes associated with the accretionary wedge off Costa Rica: Middle America trench. J. Geophys. Res., 95:8743-8752.

Snavely, P.D., Jr., and Miller, J., 1986. The central Oregon continental margin, lines WO76-4 and WO76-5. In von Huene, R. (Ed.), Seismic Images of Modern Convergent Margin Tectonic Structure. AAPG Stud. Geol., 26:24-29.

Tissot, B.P., and Welte, D.H., 1984. Petroleum Formation and Occurrence ( 2 nd ed.): Heidelberg (Springer).

Tobin, H.J., Moore, J.C., and Moore, G.F., 1994. Fluid pressure in the frontal thrust of the Oregon accretionary prism: experimental constraints. Geology, 22:979-982.

Westbrook, G.K., 1991. Geophysical evidence for the role of fluids in accretionary wedge tectonics. Philos. Trans. R. Soc. London A, 335:227-242.

Date of initial receipt: 2 September 1994

Date of acceptance: 24 March 1995

Ms 146SR-224 